\title{
Lyhenevä lapsuus katoava aikuisuus
}

Neil Postman, Lyhenevä lapsuus (suom. Ilkka Rekiarvo), WSOY, Juva 1985.

Lapsuuden käsite on katoamassa. Lapsuus on Neil Postmanin kantavan näkemyksen mukaan syntynyt Gutenbergin kirjapainotaidon aiheuttaman viestintämurroksen ja lukutaidon myötä. Nyt lapsuuden käsite on katoamassa "morselaisen murroksen", lennättimen keksimisen ja sen jälkeisen visuaalisen viestinnän jälkiseurauksiin.

Postman ei polemisoi ainoastaan lapsuuden käsitteen häviämisestä. Hänen mukaansa myös traditionaalinen aikuisuuden käsite, aikuisuus auktoriteettina, häviää samanaikaisesti lapsuuden kanssa: nykyaikaisen lapsuuden paradigma on samalla aikuisuuden paradigma. Ihmisistä tulee lapsiaikuisia tai aikuislapsia.

Ihmisten elämänkaari muuttuu ja supistuu aiemmasta lapsuus, nuoruus, aikuisuus, vanhuus -jaksottelusta. Lasten ei ole enää nykyisen sähköisen viestinnän keskellä mahdollista vaihe vaiheelta kasvaa ja kypsyä aikuisuuteen. He saavat koko aikuisuuden sisältämän väkivaltaisuuden, häpeämättömän seksuaalisuuden, kyynisyyden, poliittisen pimeyden ja muut aikuismaailman ristiriitaisuudet tietoonsa - jo lapsuudessa. Aikuisten, kodin ja koulun tiedon haltijoiden sijalle on noussut "tiedon" välittäjänä sähköinen viestintä, tärkeimpänä televisio.

Postman on moralisti. Hän varoittaa sormi pystyssä opettajamaiseen tapaan viestintäkehityksestä, joka tuhoaa lapsuuden ja samalla hänen mukaansa sivilisaatiomme perustan sekä palauttaa meidät keskiaikaan. Postmanin moraalisen herättäjän asenne selittänee kirjan paatoksen, mutta osittain myös perustelemattomuuden sähköisen viestinnän kaikkivoivassa pahuudessa ja lapsuuden ihanteellistamisessa.

Postman idealisoikin viestinnän käsitteen, tekee siitä kaikkivoivan yhteiskunnan liikuttajan ja kulttuurin kantajan. Viestinnän kaikkivoipuus perustuu Postmanilla 
kuvallisen viestinnän hallinnan mahdottomuuteen. Visuaalisen viestinnän siirtonopeus, erityisesti televisiomaisen lyhyet otokset merkitsevät Postmanin mukaan ihmismielen nopeutumista. Televisiomainen esitystapa käyttää kerrontaa, ei selitä, sen tehokeinona on kaiken, jopa uutisten dramatisointi. Se muuttaa kaiken tarinaksi, esittää kuvia ja kertomuksia, jotka ovat lapsuuden maailmalle ominaisia. Postmanin mukaan tv-ohjelmat onkin suunniteltu lähinnä 12-vuotiaiden tasoisille. Hän kysyykin mikä vaikutus aikuisiin on kulttuurilla, jossa kuvat ja kertomukset ovat hallitsevassa asemassa.

Viestintä on muuttunut kirjallisesta, analyyttisestä visuaaliseksi, ei-analyyttiseksi, rationaalisesta emotionaaliseksi ja kognitiivisesta regressiiviseksi. Visuaalinen viestintä on primitiivistä, sillä se vaatii Postmanin mukaan välitöntä havainnointia, vain hahmojen tunnistamista eikä lainkaan ymmärtämistä. Kun Postman latistaa havainnon välittömäksi havainnoksi, hän unohtaa, että inhimilliseen havaintoon liittyy aina jonkinasteinen ymmärtämisen näkökulma sekä kohteen tulkinta.

Postmanille visuaalisen viestinnän peikko näyttäytyy lähinnä amerikkalaisen television muodossa. Oikeutetusti hän kritisoi sitä (ja monien muidenkin maiden ohjelmistoa) alempitasoisen viestinnän muotona mutta samalla brutalisoi myös kaiken muun visuaalisen viestinnän ja näkee maailman pahuuden yhdentyneenä siihen. Hänen mukaansa tv:n katseluun ei tarvita mitään taitoja eikä se myöskään kehitä niitä. Postman ei tunnusta, että visuaaliselle viestinnälle voisi asettaa älyllisyyden vaatimuksen, että asiat voitaisiin esittää yhteyksissään, että katsojalle voitaisiin sen avulla ilmaista erilaisia tasoja. Otosten pituuksia voi vaihdella ja leikkauksilla luoda niihin yllätyksellisyyttä.
Dramatiikan avulla katsojassa on mahdollista herättää ideoita, oivalluksia, kysymyksiä.

Postman kieltää visuaalisen kieliopin, visuaalisen lukutaidon olemassaolon, hän ei usko valistukseen eikä siten mahdollisuuteen opettaa visuaalisen viestinnän kieltä, sen sisältämiä eri tasoja. Hän näkee kasvatuksellisena mahdollisuutena ja lapsuuden pelastajana ainoastaan sensuurin: lapsia estetään näkemästä aikuisille tarkoitettuja ohjelmia. Käytännössä Postmanin mukaan se tuskin on mahdollinen taistelukeino kaikenläpäisevää kaupallista tiedonvälitystä vastaan.
Kun Postman brutalisoi visuaalisen viestinnän, hän idealisoi kirjan ja lukutaidon lasta vaihe vaiheelta aikuisuuteen ja sen sisältämään analyyttisyyteen, kärsivällisyyteen, objektiivisuuteen, abstrahointikykyyn, loogisuuteen, häpeän ymmärtämiseen jne. kypsyttävänä. Mutta Postman unohtaa, että sen kaltainen lapsuus, ylimpään potenssiinsa korotettuna (kuten aikuisuuskin) on aina ollut harvojen etuoikeus. Lapsilla ja aikuisilla on aina ollut tapana valikoida lukemansa, jopa jättää kokonaan lukematta.

Helena Ala-Mettälä 